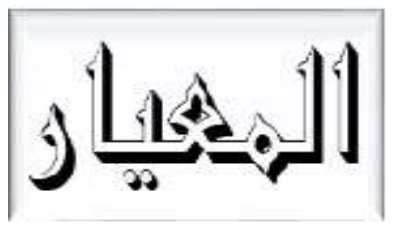

Al Mi'yar

Vol. 3, No. 2, Oktober 2020

P-ISSN: 2620-6749, E-ISSN: 2620-6536

DOI: $10.35931 / a m . v 3 i 1.340$

\title{
Feasibility Test for Learning Innovation on Arabic Teaching in Indonesian Higher Education: Study on Tarkib Mukatstsaf Ibtida'i
}

\author{
Moh. Fauzan', Titis Thoriquttyas ${ }^{2}$, Moch. Wahib Dariyadi ${ }^{3}$ \\ Universitas Negeri Malang, Indonesia
}

Email: fauzan.fs@um.ac.id¹, titisthoriq.fs@um.ac.id², wahib.fs@um.ac.id ${ }^{3}$

\begin{abstract}
The emergency of the new era, namely industrial era 4.0, is a challenge and opportunity in all aspects of life, including education's field. Along with the emergence of challenges and opportunities, there needs to be new breakthroughs in innovation for developing the learning courses, namely Tarkib Mukatstsaf Ibtida'i. This course is a compulsory subject for students of the Department of Arabic Letter, Faculty of Letters, State University of Malang (JSA, FS, UM). This study was designed to test the feasibility of android-based Arabic language learning innovations in tertiary institutions. The subjects of this study were students of JSA, FS, UM as respondents, lecturers of educational technology departments, UM as media experts and lecturers of arabic letter, UM as material experts. The results of the validation test of Tarkib Mukatstsaf Ibtida'i's teaching materials product conducted by material experts are 95\%, which means these teaching materials are very valid and very feasible to be used in learning. The results of validation from media experts, the value of this product is $95.38 \%$ means that this teaching material is very valid and very feasible to be used in learning. While the average results of the assessment from correspondents amounted to $82.35 \%$, meaning that these teaching material products are very valid and sifted worthy to be used in learning
\end{abstract}

Keyword: Tarkib Mukatstsaf Ibtida'i, feasibility test

\begin{abstract}
Abstrak
Munculnya era baru yaitu era industri 4.0 menjadi tantangan dan peluang dalam segala aspek kehidupan dan termasuk di dalamnya yaitu dunia pendidikan. Seiring munculnya tantangan dan peluang tersebut perlu adanya terobosan baru dalam inovasi pengembangan matakuliah, salah satunya pada Tarkib Mukatstsaf Ibtida'i. Mata kuliah ini merupakan matakuliah wajib bagi mahasiswa Jurusan Sastra Arab, Fakultas Sastra, Universitas Negeri Malang (JSA, FS, UM). Penelitian ini dirancang untuk menguji kelayakan terhadap inovasi pembelajaran bahasa arab berbasis android
\end{abstract}


Moh. Fauzan, Titis Thoriquttyas, Moch. Wahib Dariyadi: Feasibility Test for Learning Innovation on Arabic Teaching in Indonesian Higher Education: Study on Tarkib Mukatstsaf Ibtida'i

di perguruan tinggi. Subjek penelitian ini adalah mahasiswa JSA, FS, UM sebagai responden, Dosen Jurusan Teknologi Pendidikan, UM sebagai ahli media dan Dosen Jurusan Sastra Arab, UM sebagai ahli materi. Hasil uji validasi produk bahan ajar Tarkib Mukatstsaf Ibtida'i yang dilakukan oleh ahli materi adalah 95\% artinya bahan ajar ini sangat valid dan sangat layak untuk digunakan dalam pembelajaran. Hasil validasi dari ahli media, nilai produk ini adalah 95,38\% artinya bahan ajar ini sangat valid dan sangat layak untuk digunakan dalam pembelajaran. Sedangkan rerata hasil penilaian dari koresponden sebesar $82,35 \%$, artinya produk bahan ajar ini sangat valid dan sangat layak untuk digunakan dalam pembelajaran.

Kata Kunci: tarkib mukatstsaf ibtida'i, uji kelayakan

\section{INTRODUCTION}

Teaching materials play an important role in the learning process. Teaching material is not only a guideline that must be learned in every learning stages, but also becomes learning material and training for students ${ }^{1}$. Teaching materials are classified into two based on whether they are printed or not, namely printed and non-printed teaching materials ${ }^{2}$. With the emergence of a new era, namely the industrial era 4.0, non-printed teaching materials are certainly very necessary to answer the challenge.

The emergence of industrial era 4.0, is a challenge and opportunity in all aspects of life, including the education ${ }^{3}$. Currently, the biggest book circulation is still dominated by printed books, this is certainly an opportunity to come up with non-printed books as a solution to the era of the industrial revolution 4.0, one of which is through the preparation of non-printed books that can be made based on android applications.

This research focuses on the development of Tarkib Mukatstsaf Ibtida'i course teaching material which is a compulsory subject for students of the Department of Arabic letter, Faculty of Letters, State University of Malang (JSA, FS, UM). Along with the emergence of the industrial revolution 4.0 era, there

1 Azhari Azhari, "Inovasi Media Pembelajaran Bahasa Arab Berbasis E-Learning," CIRCUIT: Jurnal Ilmiah Pendidikan Teknik Elektro 3, no. 1 (2019): 40-47; Umi Salamah dan Triyo Supriyatno, "Innovations For Active Arabic With the Kitab Al-Wajiz Fillughoti Wa Nahwi/Inovasi Aktif Berbahasa Arab dengan Kitab Al-Wajiz Fillughoti wa Nahwi," Ijaz Arabi Journal of Arabic Learning 3, no. 1 (2020).

${ }^{2}$ Darisy Syafaah, "Inovasi Pembelajaran Bahasa Arab pada Prodi Bahasa dan Sastra Arab IAIN Tulungagung dalam Menghadapi Tantangan Era Industri 4.0," Prosiding Konfererensi Nasional Bahasa Arab 5, no. 5 (2019): 849-859.

3 Umar Faruq dan Mokhammad Miftakhul Huda, "Bahasa Arab Berbasis Peningkatan Pembelajaran Hots (Higher Order Thinking Skills) (Kajian Pembelajaran Bahasa Arab Di Madrasah Aliyah Unggulan Darul 'Ulum Step 2 Kemenag RI),” Al-Hikmah: Jurnal Kependidikan Dan Syariah 8, no. 1 (2020): 1-20. 
Moh. Fauzan, Titis Thoriquttyas, Moch. Wahib Dariyadi: Feasibility Test for Learning Innovation on Arabic Teaching in Indonesian Higher Education: Study on Tarkib Mukatstsaf Ibtida'i

needs to be a new breakthrough in this course, one of these breakthroughs is the preparation of Tarkib Mukatstsaf Ibtida'i learning innovations with a focus on Android-based teaching materials.

Tarkib Mukatstsaf Ibtida'i is a compulsory subject that must be taken by students of JSA UM. This course is a preamble or as an introduction to understanding Arabic grammar material (nahwu and sharf) 4 . This course was presented before the Tarkib Mukatstsaf Tsanawi course and the prerequisites for taking Nahwu I.

Based on the observations of researchers, some students consider tarkib subjects, both nahwu or sharf, to be difficult subjects. This is one of the problems that must be formulated. In research conducted by Humairoh, Arina Faiqoh, and Faisal Hendra (2018) there were two things that caused the low motivation of students, namely due to internal and external problems ${ }^{5}$. The internal problematic is the feeling of fear when learning, lacking certain subjects, lack of vocabulary mastery, feeling lazy, and lack of confidence. The external problematic is the absence of bi'ah Arabiyyah (Arabic language environment) in the student environment, the lack of conditions that force students to learn Arabic, not all lecturers are able to understand the individual differences of each student, the compulsion to choose majors Arabic from family or other people, and different school backgrounds between one student and another.

Therefore, it is necessary to have an interesting breakthrough to overcome the problems of these students when learning Tarkib Mukatstsaf Ibtida'i material. Among these interesting breakthroughs is to develop teaching materials based on the Android application Tarkib Mukatstsaf Ibtida'i.

The previous research related to nahwu has been carried out by Hanafi (2006) with the title "Development of Nahwu Teaching Materials Through Reconstruction of Al-Nawawi Tajdid Model Materials", his findings suggest that the development of teaching materials makes it easy for Arabic learners to understand Nahwu's rules. Similar research was also conducted by Khasairi (2000) with the title "Developing Nahwu I Teaching Material for Discourse Based on Using Interactive CDs", the results of the study stated that the teaching material produced was interesting and could increase student

4 Moh Fauzan dan Moch Wahib Dariyadi, "Pengembangan Bahan Ajar Matakuliah Tarkib Mukatstsaf Ibtida'i Berbasis Android Bagi Mahasiswa Jurusan Sastra Arab Fakultas Sastra Universitas Negeri Malang," 2019.

${ }^{5}$ Azhari, "Inovasi Media Pembelajaran Bahasa Arab Berbasis E-Learning." 
Moh. Fauzan, Titis Thoriquttyas, Moch. Wahib Dariyadi: Feasibility Test for Learning Innovation on Arabic Teaching in Indonesian Higher Education: Study on Tarkib Mukatstsaf Ibtida'i

motivation in learning 6 . But no one has yet discussed the development of Android-based teaching materials, especially in the Tarkib Mukatstsaf Ibtida'i course.

On this basis, researchers formulated research topics on Arabic learning innovation in Higher Education by taking focus on android-based teaching materials. However, in this article, the researcher concentrated more on the results of the feasibility test on the innovation of the development of teaching materials by taking from three perspectives, namely material experts, media experts and respondents. This research is different from the research mentioned above. Research conducted by Hanafi relating to tajdid al-Nahwi, Khasairi is related to the development of interactive CDs on Nahwu I.

The material experts in this study are experts or practitioners of Arabic learning that are relevant to the Tarkib Mukatstsaf Ibtida'I course, namely Lecturers from the Department of Arabic Letter, Faculty of Letters, UM with Ph.D. or Professor qualifications. While the media experts in this study refer to learning media experts from the Department of Educational Technology, UM. Furthermore, the respondents come from a sample of students who were taking the Tarkib Mukatstsaf Ibtida'I course.

\section{RESEARCH METHOD}

Validity test in the dimension of teaching materials involves lecturers who have expertise in the field of Arabic Language Education, so it is expected to provide an optimal response in measuring these learning innovations. The lecturers involved were Lecturers of Arabic Letter, Faculty of Letters, State University of Malang.

The validity test in the field of learning media involves lecturers from the Department of Educational Technology, Faculty of Education, State University of Malang. Meanwhile, the field test involved students of the Department of Arabic Letter, Faculty of Letters, State University of Malang, which were spread over several different semesters. This is expected to increase the reliability of this research.

Collecting the data through a focused group discussion (FGD) and documentation as well as a questionnaire sheet involving cross-scientific academics that enriched the perspective in this study. The type of data generated in this study is in the form of qualitative data and quantitative data. Qualitative data come from interviews with Tarkib Mukatstsaf Ibtida'i

\footnotetext{
${ }^{6}$ Syafaah, "Inovasi Pembelajaran Bahasa Arab pada Prodi Bahasa dan Sastra Arab IAIN Tulungagung dalam Menghadapi Tantangan Era Industri 4.0.”
} 
Moh. Fauzan, Titis Thoriquttyas, Moch. Wahib Dariyadi: Feasibility Test for Learning Innovation on Arabic Teaching in Indonesian Higher Education: Study on Tarkib Mukatstsaf Ibtida'i

lecturers. Quantitative data come from the results of a questionnaire distributed to students who were taking Tarkib Mukatstsaf Ibtida'i's teaching courses. While the research instruments used to collect data in the form of interview guidelines, validation sheets, questionnaires, and recording devices. Data analysis techniques used include data identification, data grouping, presentation and explanation of data contents, and inference. Data techniques used in quantitative data are the percentage data analysis. The formula used as stated by Toifah is ${ }^{7}$ :

$\begin{array}{ll}\mathrm{P} & =\frac{\text { TSe }}{\text { TSh }} \times 100 \% \\ \mathrm{P} & : \text { Percentage } \\ \text { Tse } & : \text { Total empirical score of all respondents in } 1 \text { item } \\ \text { TSh } & : \text { Total maximm socre in } 1 \text { item } \\ 100 \% & : \text { Constants }\end{array}$

The eligibility criteria are as follows:

\section{Table 1. \\ Percentage of Eligibility}

\begin{tabular}{ll}
\hline \multicolumn{1}{c}{ Percentage } & \multicolumn{1}{c}{ Eligibility } \\
\hline $\mathbf{8 1 - 1 0 0 \%}$ & Very valid and can be used without repairs \\
\hline $\mathbf{6 1 - 8 0} \%$ & Fairly valid and can be used but with improvements \\
\hline $\mathbf{4 1 - 6 0 \%}$ & Invalid and not recommended \\
\hline $\mathbf{2 1 - 4 0 \%}$ & Invalid and cannot be used \\
\hline $\mathbf{0 - 2 0 \%}$ & Very invalid and cannot be used \\
\hline
\end{tabular}

\section{DISCUSSION}

\section{a. Tarkib Mukatstsaf Ibtida'i: An Academic Course}

Tarkib Mukatstsaf Ibtida'i is a compulsory subject presented by the Arabic Letter Department, the Faculty of Letters, State University of Malang (JSA UM) in semester I. This course is an introductory course in Arabic grammar (Nahwu and Sharf) for the beginner level. This course is a pre-loaded course for Tarkib Mukatstsaf Tsanawi. This course code is PARA626 with 2

${ }^{7}$ Nur Toifah, Inovasi pembelajaran Bahasa Arab berbasis pendidikan karakter (Literasi Nusantara, 2019). 
Moh. Fauzan, Titis Thoriquttyas, Moch. Wahib Dariyadi: Feasibility Test for Learning Innovation on Arabic Teaching in Indonesian Higher Education: Study on Tarkib Mukatstsaf Ibtida'i

credits in 2 hours of meeting 8 .

The description of this course is contained in the catalog of the 2017 edition of Arabic Literature as follows. Students master the theory and are able to apply, analyze, and make decisions responsibly in the field of simple tarkib I. Topics include: anmath al-tarakib wa al-jumal (sentence of ismiyyah, fi'liyah, tarkib athfi, tarkib washfi, and tarkib idhafi, al-nafy wa alistifham $)^{9}$. Learning methods with lectures covers through the discussions, simple language analysis, and memorization. In this course students are introduced to nahwu and sharf as one of the main keys in understanding Arabic. Because it is still at the beginner level, the examples are still simple, namely in sentences and paragraphs that have not yet arrived at the examples in a text.

Based on observations in the field, there are several learning methodologies of Tarkib Mukatstsaf Ibtida'i including inductive and deductive methods.

1. Inductive Method

This method is practiced by presenting examples (amtsilah) first. After studying the examples provided, students with the guidance of educators draw their own conclusions about the rules of language based on these examples. After that students are asked to make their own examples ${ }^{10}$. In this way students are active in learning and are able to apply material that has been learned directly. And the rules learned are not just theories but can also be applied. So it can be concluded the order of presentation in the inductive teaching material as follows, (1) examples in the form of phrases, sentences, and paragraphs, (2) the conclusion of the rules learned, and (3) exercises for applying the

${ }^{8}$ Moh Fauzan, "Teori Dan Penerapan Pengembangan Bahan Ajar Sintaksis Bahasa Arab Berdasarkan Metode Induktif," Prosiding Konfererensi Nasional Bahasa Arab 5, No. 5 (2019): 362-376; Fauzan Dan Dariyadi, "Pengembangan Bahan Ajar Matakuliah Tarkib Mukatstsaf Ibtida'i Berbasis Android Bagi Mahasiswa Jurusan Sastra Arab Fakultas Sastra Universitas Negeri Malang."

${ }^{9}$ Fauzan Dan Dariyadi, "Pengembangan Bahan Ajar Matakuliah Tarkib Mukatstsaf Ibtida'i Berbasis Android Bagi Mahasiswa Jurusan Sastra Arab Fakultas Sastra Universitas Negeri Malang."

${ }_{10}$ Rahmad Arif Setiawasn Fajar Syah Alam, "Implementasi Program Pemantapan Bahasa Arab Dan Shahsiah Mahasiswa Istanbul Sabahattin Zaim Universitesi (Izu) Tahun 2019," Prosiding Konfererensi Nasional Bahasa Arab 5, No. 5 (2019): 191-198. 
Moh. Fauzan, Titis Thoriquttyas, Moch. Wahib Dariyadi: Feasibility Test for Learning Innovation on Arabic Teaching in Indonesian Higher Education: Study on Tarkib Mukatstsaf Ibtida'i

rules ${ }^{11}$.

2. Deductive Method.

This method begins with the provision of rules that must be understood and memorized, then examples are given. After that students are given the opportunity to do exercises to apply the rules or formulas given ${ }^{12}$. The advantage of this method is that it makes it easier for adult students to understand the theory right away. But the lack of methods is that students are only preoccupied with memorizing the rules and lacking the application of the learned rules. From this explanation, it can be concluded that the order of presentation in deductive teaching material is as follows, (1) the conclusion of the rules learned, (2) examples in the form of phrases, sentences and paragraphs, and (3) exercises for applying the rules ${ }^{13}$.

Between the two methods above the researcher chooses the inductive method. This method that requires active interaction between educators and students. Teaching material developed starts by displaying examples of certain rules, followed by concluding in terms of the rules, after which exercises are displayed to improve students' understanding. The results of the exercise can be used as a value of the task by educators.

A form of learning innovation that has been developed by the research team targeting sectors related to teaching materials in the Tarkib Mukatstsaf Ibtida'I course. The concrete form of learning innovation is, as follows:

11 Roviin Roviin, "Binā'al Nazhariyah Al Lughawiyyah Fî Al Turast Al 'Arabiy Wa Taqwîmuhā," Al Mi'yar: Jurnal Ilmiah Pembelajaran Bahasa Arab Dan Kebahasaaraban 3, No. 2 (2020): 151-172.

12 Syafaah, "Inovasi Pembelajaran Bahasa Arab Pada Prodi Bahasa Dan Sastra Arab Iain Tulungagung Dalam Menghadapi Tantangan Era Industri 4.0.”

${ }^{13}$ Nurul Isnaini Dan Nurul Huda, "Pengembangan Media Pembelajaran Kosakata Bahasa Arab Berbasis Permainan My Happy Route Pada Siswa Kelas Viii Mtsn 10 Sleman," Al Mi'yar: Jurnal Ilmiah Pembelajaran Bahasa Arab Dan Kebahasaaraban 3, No. 1 (2020): 1-14. 
Moh. Fauzan, Titis Thoriquttyas, Moch. Wahib Dariyadi: Feasibility Test for Learning Innovation on Arabic Teaching in Indonesian Higher Education: Study on Tarkib Mukatstsaf Ibtida'i

\section{Picture 1.}

Cover Screen of Innovation on android-based Learning material

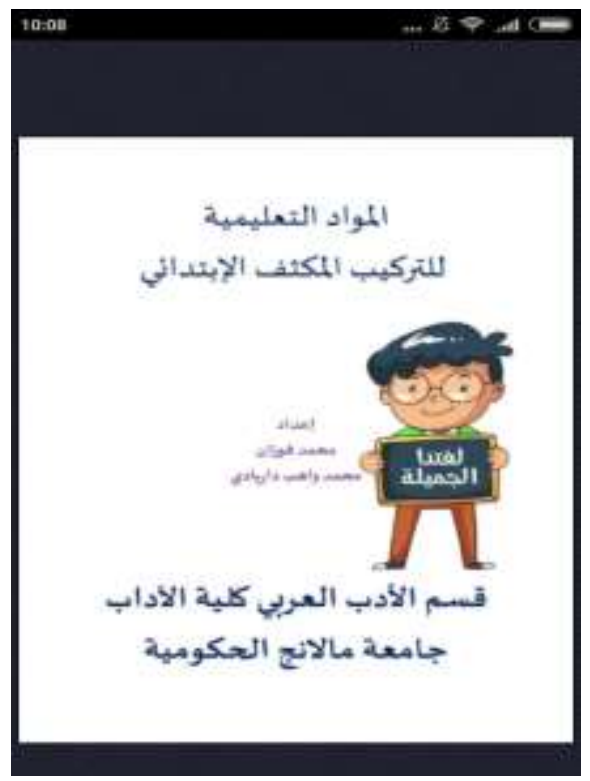

\section{b. Feasibility Test from Learning Material's Perspective}

To find out the advantages and disadvantages of the product produced, of course the product needs to be evaluated. In the trial there are two things that will be done, namely expert evaluation and small group testing. Expert evaluation, carried out by providing the results of products that have been developed to learning media experts and learning material experts Tarkib Mukatstsaf Ibtida'i. Both experts will assess, validate, and provide input on the products produced. To improve the product, the resulting product will also be discussed with Tarkib Mukatstsaf Ibtida'i lecturers. To obtain data from the trial, questionnaires and interview guidelines were used which were related to the products tested.

This study photographed the results of the validity test that took aim at teaching material that had been developed by the research team. The validity test results are as follows: 
Moh. Fauzan, Titis Thoriquttyas, Moch. Wahib Dariyadi: Feasibility Test for Learning Innovation on Arabic Teaching in Indonesian Higher Education: Study on Tarkib Mukatstsaf Ibtida'i

Table 2.

Result for Feasibility Test from Learning Material's Dimension

\begin{tabular}{|c|c|c|c|c|c|c|}
\hline \multirow[t]{2}{*}{ No } & \multirow[t]{2}{*}{ Indicators } & \multicolumn{5}{|c|}{ Score } \\
\hline & & 1 & 2 & 3 & 4 & 5 \\
\hline 1 & $\begin{array}{l}\text { Completeness of android-based Tarkib } \\
\text { Mukatstsaf Ibtida'i's teaching materials }\end{array}$ & & & & & $\sqrt{ }$ \\
\hline 2 & $\begin{array}{l}\text { The extent of Tarkib Mukatstsaf Ibtida'i's } \\
\text { teaching materials }\end{array}$ & & & & & $\sqrt{ }$ \\
\hline 3 & $\begin{array}{l}\text { The depth of Android-based Tarkib } \\
\text { Mukatstsaf Ibtida's teaching material }\end{array}$ & & & & & $\sqrt{ }$ \\
\hline 4 & $\begin{array}{l}\text { The collection of Tarkib Mukatstsaf Ibtida'i } \\
\text { teaching materials based on Android starts } \\
\text { from easy topics to difficult topics }\end{array}$ & & & & & $\sqrt{ }$ \\
\hline 5 & $\begin{array}{l}\text { Android-based Tarkib Mukatstsaf Ibtida's } \\
\text { teaching material is easy to understand }\end{array}$ & & & & & $\sqrt{ }$ \\
\hline 6 & $\begin{array}{l}\text { Validity of the content of Android-based } \\
\text { teaching material Tarkib Mukatstsaf Ibtida'i } \\
\text { is presented }\end{array}$ & & & & & $\sqrt{ }$ \\
\hline 7 & $\begin{array}{l}\text { The suitability of Tarkib Mukatstsaf Ibtida'i's } \\
\text { teaching materials based on Android with the } \\
\text { ability of students }\end{array}$ & & & & $\sqrt{ }$ & \\
\hline 8 & $\begin{array}{l}\text { Clarity description of Tarkib Mukatstsaf } \\
\text { Ibtida'i's teaching materials based on } \\
\text { Android }\end{array}$ & & & & $\sqrt{ }$ & \\
\hline 9 & $\begin{array}{l}\text { Completeness of the contents of Android- } \\
\text { based Tarkib Mukatstsaf Ibtida'i starting from } \\
\text { examples, rules, and evaluations. }\end{array}$ & & & & & $\sqrt{ }$ \\
\hline 10 & $\begin{array}{l}\text { Appropriateness of Android-based Tarkib } \\
\text { Mukatstsaf Ibtida'i training materials with } \\
\text { material }\end{array}$ & & & & & $\sqrt{ }$ \\
\hline 11 & $\begin{array}{l}\text { Variations in the form of questions about } \\
\text { teaching materials Tarkib Mukatstsaf Ibtida'i } \\
\text { based on Android }\end{array}$ & & & & & $\sqrt{ }$ \\
\hline 12 & $\begin{array}{l}\text { Levels of difficulty regarding Android-based } \\
\text { Tarkib Mukatstsaf Ibtida'i teaching materials }\end{array}$ & & & & $\sqrt{ }$ & \\
\hline
\end{tabular}


Moh. Fauzan, Titis Thoriquttyas, Moch. Wahib Dariyadi: Feasibility Test for Learning Innovation on Arabic Teaching in Indonesian Higher Education: Study on Tarkib Mukatstsaf Ibtida'i

\section{Accumulation Score}

57

\section{Percentage}

$57 / 60 \times 100=95 \%$

\section{Very Valid}

From the table above, it can be concluded that the Tarkib Mukatstsaf Ibtida'i course material based on android applications that have been produced according to material experts is very valid, while the percentage of validity and eligibility is $95 \%$.

\section{c. Feasibility Test from Learning Media's Perspective}

The feasibility test of teaching materials in terms of learning media is conducted by lecturers who have expertise in the field (Lecturers of Educational Technology, FIP, UM). To obtain data from the trial, questionnaires and interview guidelines were used which were related to the products tested.

Table 2.

Result for Feasibility Test from Learning Media's Dimension

\begin{tabular}{lllll}
\hline No & \multicolumn{1}{c}{ Indicators } & \multicolumn{3}{c}{ Score } \\
\cline { 3 - 4 } & \multicolumn{1}{c}{$\mathbf{2}$} & $\mathbf{3}$ & $\mathbf{4}$ & $\mathbf{5}$ \\
\hline $\mathbf{1}$ & $\begin{array}{l}\text { Learning Tarkib Mukatstsaf Ibtida'i using this } \\
\text { Android-based interactively. }\end{array}$ & & $\sqrt{ }$ \\
\hline $\mathbf{2}$ & $\begin{array}{l}\text { The ease of operation of Tarkib Mukatstsaf } \\
\text { Ibtida'i's teaching materials based on Android }\end{array}$ & & $\sqrt{ }$ \\
\hline $\mathbf{3}$ & $\begin{array}{l}\text { The effectiveness of the Tarkib Mukatstsaf } \\
\text { Ibtida'i teaching product based on Android }\end{array}$ & $\sqrt{ }$ \\
\hline $\mathbf{4}$ & $\begin{array}{l}\text { Clarity of writing (font type, font size, and font } \\
\text { color) products Tarkib Mukatstsaf Ibtida'i }\end{array}$ & $\sqrt{ }$ \\
teaching materials based on Android & $\begin{array}{l}\text { Organizing the order of material, examples, } \\
\text { and exercises for Android-based Tarkib } \\
\text { Mukatstsaf Ibtida'i }\end{array}$ & \\
\hline $\mathbf{6}$ & $\begin{array}{l}\text { Design and appearance of Tarkib Mukatstsaf } \\
\text { Ibtida'i's teaching materials based on Android }\end{array}$ & $\sqrt{ }$ \\
\hline
\end{tabular}


Moh. Fauzan, Titis Thoriquttyas, Moch. Wahib Dariyadi: Feasibility Test for Learning Innovation on Arabic Teaching in Indonesian Higher Education: Study on Tarkib Mukatstsaf Ibtida'i

7 The menu and features of this Android-based Tarkib Mukatstsaf Ibtida'i teaching material are complete

8 The complete Tarkib Mukatstsaf Ibtida'i teaching material in Android (theory, examples and exercises)

9 The winning design of Android-based Tarkib Mukatstaf Ibtida'i teaching materials

10 The accuracy of the spacing (spacing) of this Android-based Tarkib Mukatstsaf Ibtida'i teaching material is complete

11 The suitability of the exercises presented in the Tarkib Mukatstsaf Ibtida'i teaching materials based on Android with the material presented

12 Variations of exercises presented in the Tarkib Mukatstsaf Ibtida'i teaching materials based on Android

13 Variations of assignment presented in the Tarkib Mukatstsaf Ibtida'i teaching materials based on Android

Accumulation Score

Percentage

$62 / 65 \times 100=95,38 \%$
62

Very Valid

From this table, it can be concluded that the Tarkib Mukatstsaf Ibtida'i course material based on Android applications that have been produced, according to media experts, is very valid, while the percentage of validity and eligibility is $95 \%$.

\section{d. Feasibility Test from Respondent Responses's Perspective}

The field test was carried out by applying the produced item to a small group of ten students who were taking the Tarkib Mukatstsaf Ibtida'i course as well as the correspondent in this study. To obtain data from the trial, questionnaires and interview guidelines were used which were related to the products tested. 
Moh. Fauzan, Titis Thoriquttyas, Moch. Wahib Dariyadi: Feasibility Test for Learning Innovation on Arabic Teaching in Indonesian Higher Education: Study on Tarkib Mukatstsaf Ibtida'i

Table 3.

Result for Feasibility Test from Respondent's Dimension

\begin{tabular}{|c|c|c|c|c|c|c|}
\hline \multirow[t]{2}{*}{ No } & \multirow[t]{2}{*}{ Indicators } & \multicolumn{5}{|c|}{ Score } \\
\hline & & 1 & 2 & 3 & 4 & 5 \\
\hline 1 & $\begin{array}{l}\text { Using the Tarkib Mukatstsaf Ibtida'i } \\
\text { through Android-based is interactive } \\
\text { learning }\end{array}$ & & & 1 & 7 & 2 \\
\hline 2 & $\begin{array}{l}\text { Students have no difficulty in using this } \\
\text { Android-based Tarkib Mukatstsaf Ibtida'i } \\
\text { teaching material }\end{array}$ & & & 4 & 5 & 1 \\
\hline 3 & $\begin{array}{l}\text { This Android-based Tarkib Mukatstsaf } \\
\text { Ibtida'i teaching material makes it easy } \\
\text { for students to learn the material }\end{array}$ & & & 1 & 9 & \\
\hline 4 & $\begin{array}{l}\text { This Tarkib Mukatstsaf Ibtida'i teaching } \\
\text { material product based on Android is } \\
\text { easy to operate }\end{array}$ & & & & 7 & 3 \\
\hline 5 & $\begin{array}{l}\text { Students felt happy in the learning to use } \\
\text { this Android-based Tarkib Mukatstsaf } \\
\text { Ibtida'i teaching material }\end{array}$ & & & 2 & 6 & 2 \\
\hline 6 & $\begin{array}{l}\text { Students are more active when learning } \\
\text { to use this Android-based Tarkib } \\
\text { Mukatstaf Ibtida'i teaching material }\end{array}$ & & & 1 & 8 & 1 \\
\hline 7 & $\begin{array}{l}\text { This Tarkib Mukatstsaf Ibtida i Android- } \\
\text { based teaching material product is able } \\
\text { to increase student motivation in } \\
\text { learning }\end{array}$ & & & 1 & 8 & 1 \\
\hline 8 & $\begin{array}{l}\text { This Tarkib Mukatstsaf Ibtida'i teaching } \\
\text { material product based on Android helps } \\
\text { students understand the material }\end{array}$ & & & 1 & 6 & 3 \\
\hline 9 & $\begin{array}{l}\text { The menu and features of this Android- } \\
\text { based Tarkib Mukatstsaf Ibtida'i teaching } \\
\text { material are complete }\end{array}$ & & & & 9 & 1 \\
\hline 10 & $\begin{array}{l}\text { This Tarkib Mukatstsaf Ibtida'i teaching } \\
\text { material for Android is complete }\end{array}$ & & & & 8 & 2 \\
\hline
\end{tabular}


Moh. Fauzan, Titis Thoriquttyas, Moch. Wahib Dariyadi: Feasibility Test for Learning Innovation on Arabic Teaching in Indonesian Higher Education: Study on Tarkib Mukatstsaf Ibtida'i

11 The material in this Android-based 64 Tarkib Mukatstsaf Ibtida'i teaching material is presented from an easy discussion to a difficult discussion

12 The exercises presented in the Android$9 \quad 1$ based Tarkib Mukatstsaf Ibtida'i are in accordance with the material provided

13 The exercises presented in the Android$7 \quad 3$ based Tarkib Mukatstsaf Ibtida'i are vary

14 The exercises in this Android-based 10 Tarkib Mukatstaf Ibtida'i teaching material help students in independent and group learning

15 The exercises presented in the Androidbased Tarkib Mukatstsaf Ibtida'i range from the easy questions to difficult question

16 After learning through this Androidbased Tarkib Mukatstaf Ibtida'i teaching material, student understanding is increases

17 This Android-based Tarkib Mukatstaf Ibtida'i teaching material deserves to be developed

\begin{tabular}{lccc}
\hline Number of student assessment results & 12 & 126 & 32 \\
\hline Student assessment results & $12 \mathrm{x}$ & 126 & 32 \\
& $3=$ & $\mathrm{x} 4=$ & $\mathrm{x} 5$ \\
& $\mathbf{3 6}$ & $\mathbf{5 0}$ & $=$ \\
& & $\mathbf{4}$ & $\mathbf{1 6}$ \\
& & & $\mathbf{0}$ \\
\hline Score & $\mathbf{7 0 0}$ & \\
\hline Percentage & \multicolumn{3}{l}{} \\
$\mathbf{7 0 0 / 8 5 0} \times \mathbf{1 0 0}=\mathbf{8 2 , 3 5 \%}$ & Very Valid \\
\hline
\end{tabular}

Seen from the table above, the percentage of the vote was $82.35 \%$ correspondent means of teaching materials for the course Tarkib Mukatstsaf Ibtida'i based Android application is very valid. 
Moh. Fauzan, Titis Thoriquttyas, Moch. Wahib Dariyadi: Feasibility Test for Learning Innovation on Arabic Teaching in Indonesian Higher Education: Study on Tarkib Mukatstsaf Ibtida'i

\section{Conclusion}

From the results of the evaluation, it can be concluded that the Tarkib Mukatstsaf Ibtida'i course material by android-based that has been produced according to material experts is very valid, while the percentage of validity and eligibility is $95 \%$. From the results of the evaluation of the media experts, it can be concluded that the Tarkib Mukatstsaf Ibtida'i course android-based application that has been produced is also very valid, while the percentage is $95.38 \%$. While the percentage of ratings from correspondents is $82.35 \%$, it means that the teaching material for the Tarkib Mukatstsaf Ibtida'i course based on the android application is very valid. After the final evaluation, based on the evaluation results, nothing should be revised from the teaching material that has been produced, because this teaching material is already very valid and can be directly applied. This is as stated by Akbar (2013: 82), if the percentage of product value produced is between $81-100 \%$, then the product is very valid and can be used without improvement.

Based on the research result, there are two suggestions that need to be considered, are as follows: 1) in using teaching materials for Tarkib Mukatstsaf Ibtida'i Android-based lecture, an explanation from the lecturer and the program maker is needed. 2) For further researchers, can conduct further research for example relating to the effective use of Tarkib Mukatstsaf Ibtida' $i$ lectures on Android-based or conduct research with the development of these teaching materials but in different objects for example is in the Tarkib Mukatstsaf Tsanawi course.

\section{Bibliography}

Alam, Rahmad Arif Setiawan Fajar Syah. "Implementasi Program Pemantapan Bahasa Arab Dan Shahsiah Mahasiswa Istanbul Sabahattin Zaim Universitesi (Izu) Tahun 2019." Prosiding Konfererensi Nasional Bahasa Arab 5, no. 5 (2019): 191-198.

Azhari, Azhari. "Inovasi Media Pembelajaran Bahasa Arab Berbasis ELearning." CIRCUIT: Jurnal Ilmiah Pendidikan Teknik Elektro 3, no. 1 (2019): 40-47.

Faruq, Umar, dan Mokhammad Miftakhul Huda. "Bahasa Arab Berbasis Peningkatan Pembelajaran Hots (Higher Order Thinking Skills)(Kajian Pembelajaran Bahasa Arab Di Madrasah Aliyah Unggulan Darul 'Ulum Step 2 Kemenag RI)." Al-Hikmah: Jurnal Kependidikan Dan Syariah 8, no. 1 (2020): 1-20. 
Moh. Fauzan, Titis Thoriquttyas, Moch. Wahib Dariyadi: Feasibility Test for Learning Innovation on Arabic Teaching in Indonesian Higher Education: Study on Tarkib Mukatstsaf Ibtida'i

Fauzan, Moh. "Teori Dan Penerapan Pengembangan Bahan Ajar Sintaksis Bahasa Arab Berdasarkan Metode Induktif." Prosiding Konfererensi Nasional Bahasa Arab 5, no. 5 (2019): 362-376.

Fauzan, Moh, dan Moch Wahib Dariyadi. "Pengembangan Bahan Ajar Matakuliah Tarkib Mukatstsaf Ibtida'i Berbasis Android Bagi Mahasiswa Jurusan Sastra Arab Fakultas Sastra Universitas Negeri Malang," 2019.

Isnaini, Nurul, dan Nurul Huda. "Pengembangan Media Pembelajaran Kosakata Bahasa Arab Berbasis Permainan My Happy Route Pada Siswa Kelas Viii Mtsn 10 Sleman." Al Mi'yar: Jurnal Ilmiah Pembelajaran Bahasa Arab dan Kebahasaaraban 3, no. 1 (2020): 1-14.

Roviin, Roviin. "Binā’al Nazhariyah Al Lughawiyyah Fî Al Turast Al 'Arabiy Wa Taqwîmuhā." Al Mi'yar: Jurnal Ilmiah Pembelajaran Bahasa Arab dan Kebahasaaraban 3, no. 2 (2020): 151-172.

Salamah, Umi, dan Triyo Supriyatno. "Innovations For Active Arabic With the Kitab Al-Wajiz Fillughoti Wa Nahwi/Inovasi Aktif Berbahasa Arab dengan Kitab Al-Wajiz Fillughoti wa Nahwi." Ijaz Arabi Journal of Arabic Learning 3, no. 1 (2020).

Syafaah, Darisy. "Inovasi Pembelajaran Bahasa Arab pada Prodi Bahasa dan Sastra Arab IAIN Tulungagung dalam Menghadapi Tantangan Era Industri 4.0." Prosiding Konfererensi Nasional Bahasa Arab 5, no. 5 (2019): 849-859.

Toifah, Nur. Inovasi pembelajaran Bahasa Arab berbasis pendidikan karakter. Literasi Nusantara, 2019. 
Moh. Fauzan, Titis Thoriquttyas, Moch. Wahib Dariyadi: Feasibility Test for Learning Innovation on Arabic Teaching in Indonesian Higher Education: Study on Tarkib Mukatstsaf Ibtida'i 